This study was supported by grants from the Finnish Foundation for Cardiovascular Research and the Ida Montin Foundation, Helsinki, Finland. CP, Bradley RF: Chrislieb aR, Soeldner JS, eds. Joslin's diabees Philadelphia: La and Febiger, 1985:553-82.

Cohn PF Silent myordialischemia: classification prevalence and prognosis. Am F. Med 1985;79: suppl 3A):2-6.

3 Asser ME. Prognosis in stable angina pectoris and silent mvocardial ischemia. A $m$ F Cardiol 1988;61:19F-21F

+ Margolis JR, Kannel WB, Feinleib M, Dawber TR, McNamara PM. Clinical features of unrecognized myocardial infarction: an update on the Framingham study. N Engl f. Med 1984;311:1144-7.

5 Bradley RF, Schonfeld A. Diminished pain in diabetic patients with acute myocardial infarction: Geriatrics 1962;17:322-6.

6 Pell S, D'Alonzo CA. Factors associated with long-term survival of diabetics. FA.MA 1970;214:1833-40.

Kannel WB, McGee DL. Diabetes and cardiovascular disease. The Framingham study. $f A M A$ 1979;241:2035-8

8 Herman JB, Medalie JH, Goldbourt U. Differences in cardiovascular morbidity and mortality between previously known and newly diagnosed adult diabetics. Diabetologia 1977;13:229-34.

9 Arstila M, Kallio V, Seppänen A. Clinical exercise testing. Standards for procedures and recommendations for the interpretation. Publications of the procedures and recommendations for the interp

10 Huikuri HV, Korhonen UR, Airaksinen KEJ, Ikäheimo MJ, Heikkilä J,
Takkunen JT. Comparison of dipyridamole-handgrip test and bicycle exercise for thallium tomographic imaging. Am 7 Cardiol 1988;61:264-8

11 Huikuri HV, Ikäheimo $M J$, Linnaluoto $M M K$, Takkunen JT. Left ventricula response to isometric exercise and its value in predicting the change in ventricular function after mitral valve replacement for mitral regurgitation. Am F Cardiol 1983;51:1110-5.

12 Chiariello $\mathrm{M}$, Indolfi $\mathrm{C}$, Cotecchia MR, Sifola C, Romano M, Condorelli $M$ Asymptomatic transient ST changes during ambulatory ECG monitoring in diabetic patients. Am Heart f 1985;110:529-34.

13 Nesto RW, Phillips RT, Kett KG, et al. Angina and exertional myocardia ischemia in diabetic and non-diabetic patients: assessment by exercise ischemia in diabetic and non-diabetic patients: assess

14 Bellet S, Roman L. The exercise test in diabetic patients as studied by radioelectrocardiography. Circulation 1967:36:245-54.

15 Abenavoli T, Rubler S, Fisher VJ, Axelrod HI, Zuckerman KP. Exercise testing with myocardial scintigraphy in asymptomatic diabetic males. Circulation 1981;63:54-6

16 Erikssen J, Thaulow E. Follow up of patients with asymptomatic myocardial ischemia. In: Rutishauser W, Roskamm H, eds. Silent myocardial ischemia. Berlin: Springer Verlag, 1984:156-64.

17 Froelicher VF, Thompson AJ, Longo MR Jr, Triebwasser JH, Lancaster MC Value of exercise testing for screening asymptomatic men for latent coronary artery disease. Prog Cardiovasc Dis 1976;18:265-76.

18 Kereiakes DJ, Naughton JL, Brundage B, Schiller NB. The heart in diabetes. West F Med 1984; 14:583-93.

19 Beller GA, Gibson RS. Sensitivity, specificity and prognostic significance of non-invasive testing for occult or known coronary disease. Prog Cardiovasc Dis $1987 ; 23(4): 241-70$.

(Accepted 25 April 1990

\title{
Infection with human $T$ cell leukaemia/lymphoma virus type I in patients attending an antenatal clinic in London
}

\author{
Jennifer H C Tosswill, A E Ades, \\ Catherine Peckham, Philip P Mortimer, \\ Jonathan N Weber
}

\author{
Virus Reference \\ Laboratory, Central Public \\ Health Laboratory, \\ London NW9 5HT \\ Jennifer H C Tosswill, MSC, \\ senior microbiologist \\ Philip P Mortimer, \\ FRCPATH, director

\section{Institute of Child Health, London WC1 \\ A E Ades, PHD, senior lecturer in medical statistics \\ Catherine Peckham, MD, professor of paediatric epidemiology}

\section{Department of Medicine,} Royal Postgraduate

Medical School, London W12 0HS

Jonathan N Weber, MRCP, senior lecturer in infectious diseases

Correspondence to: Dr Weber.

Br.1Yed J 1990;301:95-6
Infection with human $\mathrm{T}$ cell leukaemia/lymphoma virus type $I$ has often been reported in British adults originating from the Caribbean islands, ${ }^{1}$ though few data exist on the prevalence of the virus in unselected populations in the United Kingdom. In recent studies in north London fewer than $0.02 \%$ of blood donors were found to be positive for the virus (J A J Barbara, personal communication).

We assessed the prevalence of antibody to human $T$ cell leukaemia/lymphoma virus type $I$ in women attending an antenatal clinic in an area of London with an ethnically heterogeneous population and investigated whether seropositivity was confined to groups known to be at risk of carrying the virus.

\section{Patients, methods, and results}

We collected serum samples from 2956 consecutive women attending an antenatal clinic in London during 1980. The ethnic origin, country of birth, and age of each patient were recorded. The analysis was based on the 2893 women for whom complete data and sufficient serum were available. Ethical permission had been obtained for the study.

The serum was initially tested for the presence of antibody to human $T$ cell leukaemia/lymphoma virus type I by gelatin particle agglutination (Fujirebio), a very sensitive but not very specific test. All reactive samples were further tested by enzyme linked immunosorbent assay (ELISA) (Abbott and Du Pont) and competitive and IgG capture radioimmunoassay (Virus Reference Laboratory in house assays). Samples that gave a reaction in one or more of these additional assays were then tested by western blot analysis (Biotechnology Research); those that reacted with envelope proteins in the blot were confirmed as positive.

Of the 2893 serum samples tested, 130 were reactive by gelatin particle agglutination; 27 of these were reactive in additional assays, but only six were reactive in all assays including western blot and so were confirmed as positive. The results were analysed by ethnic origin and country of birth of the patients (table). All of the women confirmed as being positive for antibody to the virus were black and had been born outside the United Kingdom. The proportion of black women confirmed as positive was significantly greater in those who had been born in the Caribbean than in those who had been born in the United Kingdom $(p=0.049$, Fisher's exact one tailed test). The women who had been born in the Caribbean were, however, on average 6.6 years older than those who had been born in the United Kingdom. The numbers were low in all the groups of black women, but the results were consistent with a fairly high prevalence of antibody to the virus based on the $95 \%$ confidence interval.

\section{Comment}

In this group of antenatal patients infection with human $\mathrm{T}$ cell leukaemia/lymphoma virus type I was confined to ethnic groups already known to be at risk of carrying the virus - that is, black women who had been born in the West Indies or Africa. The highest prevalence of infection (1.9\%) was found in black women who had been born in the West Indies, which is

Distribution of antibody to human $T$ cell leukaemiallymphoma virus type I in antenatal patients according to their ethnic origin

\begin{tabular}{|c|c|c|c|c|c|c|}
\hline Ethnic origin & $\begin{array}{l}\text { Region } \\
\text { of } \\
\text { birth }\end{array}$ & $\begin{array}{c}\text { No of } \\
\text { patients } \\
(n=2893)\end{array}$ & $\begin{array}{l}\text { Mean } \\
\text { age } \\
\text { (years) }\end{array}$ & $\begin{array}{l}\text { No }(\%) \text { of serum samples } \\
\text { reactive but } \\
\text { not confirmed as positive }\end{array}$ & $\begin{array}{l}\text { No }(\%) \text { of samples } \\
\text { confirmed as } \\
\text { positive }\end{array}$ & $\begin{array}{c}\text { 95\% Confidence interval } \\
(\%)\end{array}$ \\
\hline \multirow{2}{*}{ Asian } & $\int$ Asia & 605 & $25 \cdot 5$ & $5: 0 \cdot 8$ & & 0.0 to 0.6 \\
\hline & Africa & 389 & $25 \cdot 9$ & $1(0.3)$ & & 0.0 to 0.9 \\
\hline \multirow[t]{2}{*}{ White } & United Kingdom & 997 & $25 \cdot 9$ & $3(0 \cdot 3)$ & & 0.0 to 0.4 \\
\hline & United Kingdom & 214 & $19 \cdot 5$ & $2(0.9)$ & & 0.0 to 1.7 \\
\hline \multirow[t]{2}{*}{ Black } & Africa & 135 & $27 \cdot 5$ & $5(3 \cdot 7)$ & $1(0 \cdot 7)$ & $0 \cdot 0$ to $4 \cdot 1$ \\
\hline & Caribbean & 260 & $26 \cdot 1$ & $2(0 \cdot 8)$ & $5(1.9)$ & 0.6 to 4.5 \\
\hline Other & Various & 293 & $28 \cdot 2$ & $3(1 \cdot 8)$ & & 0.0 to $1 \cdot 2$ \\
\hline
\end{tabular}


consistent with previous British reports ${ }^{2}$ and reflects the prevalence of antibody to the virus found in the same age group in the West Indies. ${ }^{3}$ No cases of infection were identified among the 214 black women who had been born in the United Kingdom, but the fairly small sample allows us to state only that the prevalence in this group was unlikely to be more than $1 \cdot 7 \%$. These women were young (mean age 19.5 years), and as there is evidence that infection can be acquired throughout adult life $^{3}$ a sample more representative in age might have shown a higher prevalence of infection.

Though the risk of maternal transmission of the virus to infants born in Japan is high, ${ }^{+}$the risk in the United Kingdom is unknown. There is also little prospective information on the importance of carriage of the virus, which makes it difficult to counsel carriers.

Our data suggest that a reservoir of undiagnosed female carriers of human $\mathrm{T}$ cell leukaemia/lymphoma virus type I exists in the United Kingdom, but before widespread screening for antibody to the virus is considered more data are needed on the prevalence of infection in other regions of the United Kingdom, the risk of transmission from mother to child, and the long term consequences of infection with the virus.

We are grateful to J E Richmond for help with handling the data.

1 Catovsky D, Rose M, Goolden AWG, et al. Adult T-cell lymphoma/leukaemi in blacks from the West Indies. Lancet 1982;i:639-43.

2 Mowbray J, Mawson S, Chawira A, et al. Epidemiology of human T-cell leukemia/lymphoma virus type I (HTLV-I) infections in a subpopulation of Afro-Carino

3 Clark J, Saxing C, Gibbs WN, et al Seroepidemich cell leukemialymphom cell leukeniahy pathway for peculiar endemia. Asian Medical fournal 1989;32:239-45.

(Accepted 3 April 1990)

\section{Hypothyroidism in polymyalgia rheumatica and giant cell arteritis: lack of any association}

\section{B Dasgupta, E Grundy, E Stainer}

\section{Departments of}

Rheumatology, Clinical

Chemistry, and

Immunology, Royal Sussex

County Hospital, Brighton,

Sussex

B Dasgupta, MRCP, senior

registrar

E Grundy, DPHIL, principal

biochemist

E Stainer, senior medical

laboratory scientific officer

Correspondence to: $\mathrm{Dr}$ B Dasgupta, Rheumatology

Unit, Guy's Hospital,

London SE1 9RT.

BrMed f 1990;301:96-7 et al.

\section{Patients, methods, and results} giant cell arteritis (based at Guy's Hospital, London).
Wiseman et al have described a study showing an association between hypothyroidism and polymyalgia rheumatica and giant cell arteritis. ${ }^{1}$ This prompted us to perform thyroid function tests and tests for thyroid antibodies on stored serum samples from patients with polymyalgia rheumatica and giant cell arteritis. Our results and conclusions differ from those of Wiseman

Serum samples obtained during two prospective studies were stored at $-20^{\circ} \mathrm{C}$. The first was a multicentre study in the South East Thames region to determine the numbers of CD8 + cells in peripheral blood in patients with polymyalgia rheumatica and The second was a study of the treatment of polymyalgia rheumatica with intramuscular methylprednisolone (based at Royal Sussex County Hospital, Brighton). Polymyalgia rheumatica and giant cell arteritis had been diagnosed from clinical features, the erythrocyte sedimentation rate, $\mathrm{C}$ reactive protein concentration, and a good response to corticosteroids. None of the patients had a history of thyroid disease or were taking thyroxine. Prior exclusion of hypothyroidism was not a criterion for entry of patients into either study.

Serum samples from 77 patients ( 69 with polymyalgia rheumatica and eight with giant cell arteritis) were studied. The mean ages of patients in the two studies were $72 \cdot 4$ and $70 \cdot 3$ years respectively. Free thyroxine and free triiodothyronine concentrations were measured indirectly by measuring total thyroxine and total triiodothyronine by a standard radioimmunoassay; measuring thyroxine binding globulin with a tracer binding assay; and then calculating the concentrations of free hormones. ${ }^{2}$ Thyroid stimulating hormone was measured by MA1A clone assay (Sero Diagnostics, Woking, Surrey). Thyroid antibodies were measured by rapid particle agglutination tests with the commercial test kits Thymune $\mathrm{T}$ and Thymune $\mathrm{M}$ (Fujirubio).

None of the 77 patients showed biochemical evidence of hypothyroidism; one was borderline for hypothyroidism and one clearly had hyperthyroidism.
Three patients had low concentrations of antibodies to thyroglobulin and microsomal antigen, and five had antibodies to microsomal antigen only.

Clinical features of hypothyroidism were not recorded in any of the 62 patients from the first study. A retrospective examination for clinical hypothyroidism, such as delayed relaxation of ankle jerks, did not show any abnormalities among the 15 patients from the second study.

\section{Comment}

Our study failed to find any association between biochemical hypothyroidism and polymyalgia rheumatica or giant cell arteritis. The study by Wiseman et al was a retrospective study of the patients' notes, and it is always difficult to ensure that all patients with a particular condition are truly included in such studies.

In their report Wiseman et al did not describe how the patients' thyroid state had been ascertained - that is, there was no indication of which thyroid function tests had been carried out. This is especially relevant because the mean age of patients in their study was high $(80.5$ years). In such patients sickness in general may be associated with a "sick euthyroid" state in which serum triiodothyronine and occasionally thyroxine concentrations are low but do not connote hypothyroidism. It would have been useful to know whether they also measured serum thyroid stimulating hormone concentrations.

Another possible explanation might be that hypothyroidism in itself may present with quite severe myalgia, muscle stiffness, and a raised creatine kinase concentration and thus mimic polymyalgia rheumatica or myositis. We wonder whether this factor might have accounted for the high incidence of hypothyroidism (nine out of 15) seen by Wiseman et al in their patients with polymyalgia rheumatica.

Because polymyalgia rheumatica, giant cell arteritis, and hypothyroidism are fairly common conditions in the elderly, the coincidental development of two separate diseases in the same patient might explain why there are reports of these conditions coexisting. In our study the thyroid antibody concentrations in the serum samples were all low and were no higher than those in the general population. ${ }^{3}$ The only autoantibodies that occur in higher concentrations in polymyalgia rheumatica and giant cell arteritis are antibodies to intermediate filaments.

We think that hypothyroidism is an important differential diagnosis in the clinical presentation of polymyalgia rheumatica but that any true association 